\title{
Cinema as a Trendsetter and Source of Historical Research in Fashion
}

Maria Paula Guimarães

Master, School of Design State University of Minas / mariapauladesigndemoda@gmail.com Orcid: 0000-0002-5264-1139 / lattes

Rita Aparecida da Conceição Ribeiro

Doctor, School of Design State University of Minas / rribeiroed@gmail.com Orcid: 0000-0003-0748-854X / lattes 


\title{
Cinema as a Trendsetter and Source of Historical Research in Fashion
}

\begin{abstract}
Although it emerged in Europe in the late nineteenth century, it was in the United States that cinema had its greatest development and consolidated as a multidisciplinary production activity and its multiple styles and genres became the subject of several studies. The correct interpretation of the symbolic contents of the film project enables an understanding of the socioeconomic conditions of an era and then becomes an important source of historical research. This article proposes a classification of cinema costumes, bringing a new perspective to the understanding of films that reconstitute other periods of time, thus broadening the classification created by Betton (1987). For this article, three films of the musical genre were analyzed, considering a line of research on the cinema influence in the trendsetting of the young culture where the music constitutes a central vector. The films analyzed are: West Side Love (1961), The Saturday Night Fever (1977) and Hair (1978), classified in the categories of time period reproduction, contemporary costumes and free period of time interpretatio, allowing a more objective identification of ties between the socioeconomic reality of each period of time and the cinema, interfering in the constitution of habits and customs of a social group.
\end{abstract}

Keywords: Fashion; Cinema; History. 


\title{
O cinema Como Criador de Tendências e Fonte de Pesquisa Histórica na Moda
}

\begin{abstract}
RESUMO
Apesar de ter surgido na Europa em fins do século XIX, foi nos Estados Unidos que o cinema teve seu maior desenvolvimento e consolidou-se como uma atividade de produção multidisciplinar e seus múltiplos estilos e gêneros tornaramse objeto de vários estudos. A correta interpretação dos conteúdos simbólicos do projeto fílmico possibilita um entendimento das condições socioeconômicas de uma época tornando-se então uma importante fonte de pesquisa histórica. Este artigo propõe uma classificação dos figurinos de cinema, trazendo um novo olhar para o entendimento de filmes que reconstituem outras épocas, ampliando assim a classificação criada por Betton (1987). Para este artigo foram analisados três filmes do gênero musical, considerando uma linha de pesquisa sobre a influência exercida pelo cinema na construção de tendências da cultura jovem onde a música constitui um vetor central. Os filmes analisados são: Amor, Sublime Amor (1961), Os Embalos de Sábado à noite (1977) e Hair (1978), classificados nas categorias de reconstituição de época, figurino contemporâneo e livre interpretação de época, possibilitando a identificação mais objetiva dos laços existentes entre a realidade socioeconômica de cada época e o cinema, interferindo na constituição de hábitos e costumes de um grupo social.
\end{abstract}

Palavras Chave: Moda; Cinema; Figurino. 


\section{INTRODUCTION}

Since its emerging (1895), at the hands of the Lumière brothers, cinema is responsible for enchanting generations (SOUZA, 2005). Conceived as an instrument of recording reality, it soon became entertainment thanks to the work of the magician and illusionist Georges Méliès (1861-1938), who revealed the innumerable possibilities of manipulating the image and conceived the cinema as a spectacle. Its rapid development was the fruit of a society greedy for entertainment and the greatest impulse happened in the United States. Initially, the silent film had musical accompaniment and, often, narration of the plot, live, inside the exhibition rooms.

Still according to Souza (2005), the introduction of the sound films, that is, with recorded and synchronized soundtrack, in 1927 with the film "The Jazz Singer", caused a substantial change in the process of film production. The conception of a film begins to develop as a multidisciplinary project, involving several professionals from different areas in order to be as faithful as possible to a particular plot, usually orchestrated by a director or producer capable of promoting the perfect integration of the different areas.

Throughout the twentieth century various styles of films were emerging, new ways of filming, producing and building plots. Betton (1987) explains that they are classified by genres, those films that fit certain defined plot features such as drama, comedy, adventure, science fiction and many others. On the other hand, the way of making the films can differentiate them and several types appeared like the "noir" films, the French "nouvelle vague", the German cinema and other stylistic types, composing a rich and well defined cinematographic language. 
Cinema is, above all, art, an artistic spectacle. It is also aesthetic, poetic or musical language - with a syntax and a style; it is a figurative writing, and still a reading, a way of communicating thoughts, convey ideas and express feelings. A form of expression as broad as the other languages (literature, theater, etc.), quite elaborate and specific. Making a film is to organize a series of spectacular elements in order to provide an aesthetic, objective, subjective or poetic view of the world [...] (BETTON, 1987, p.1) ${ }^{1}$.

In addition to spectacle and entertainment, cinema can also be considered a historical source. According to Marc Ferro (1992), cinema is a subject and source of history. Cinema bases itself on events in order to create its actions. Not only for the production of documentary film, which has recorded many important historical moments, cinema, even in its fantasy, portrays a reality, or permeates through the reality which is lived in the film production. Marc Ferro, in his book "Cinema and History" emphasizes the role of cinema as a historical source that must be recognized by historians.

The film, here, is not being considered from the semiological point of view. Nor is it about aesthetics or the history of cinema. It is being observed not as a work of art, but as a product, an image-object, whose meanings are not only cinematic. It is not only valid for what it witnesses, but also for the socio-historical approach it authorizes. The analysis does not necessarily focus on the work in its entirety: it can rely on strata, search for "series", compose sets. And criticism is also not limited to the film, it integrates with the world that surrounds it and with which it communicates, necessarily. Under these conditions, it would not be enough to undertake analysis of films, sections of films, plans, themes, taking into account, as necessary, the knowledge and approach of the different human sciences. It is necessary to apply these methods to each

\footnotetext{
${ }^{1} \mathrm{O}$ cinema é, antes de mais nada, uma arte, um espetáculo artístico. É também uma linguagem estética, poética ou musical - com uma sintaxe e um estilo; é uma escrita figurativa, e ainda uma leitura, um meio de comunicar pensamentos, veicular ideias e exprimir sentimentos. Uma forma de expressão tão ampla quanto as outras linguagens (literatura, teatro, etc.), bastante elaborada e específica. Fazer um filme é organizar uma série de elementos espetaculares a fim de proporcionar uma visão estética, objetiva, subjetiva ou poética do mundo[...] (BETTON, 1987, p.1).
} 
of the substrates of the film (images, sonorized images, not sonorized) the relations between the components of these substrates; to analyze in the film both the narrative and the scenario, the writing, the relations of the film with that which is not the film: the author, the production, the public, the critic, the regime of the government. This is the only way to understand not only the work, but also the reality it represents (FERRO, 1992) $)^{2}$.

Films can be seen in various ways, as entertainment or as symbolic objects, in which various signs can be decoded in the search for an understanding of a subjective contents, which may be intentional or not. Films can also be analyzed in order to provide an understanding of the socio-cultural conditions of a given period through a reflexive analysis concerning the historical moment of the production, becoming an important reference of time.

Thus, the objective of this article is to identify the possibility of considering films as sources of historical research, through the analysis of costumes which are classified into categories, enabling the correct interpretation of the symbolic contents of the clothes and their identification within the historical context to which they refer. To illustrate this idea, three musical films were chosen, with a common theme that will be analyzed according to the proposed classification: 1) West Side Love (1961); 2) Hair (1979); 3) Saturday Night Fever (1977). (Figure 1)

\footnotetext{
${ }^{2} \mathrm{O}$ filme, aqui, não está sendo considerado do ponto de vista semiológico. Também não se trata de estética ou de história do cinema. Ele está sendo observado não como uma obra de arte, mas sim como um produto, uma imagemobjeto, cuja significações não são somente cinematográficas. Ele não vale somente por aquilo que testemunha, mas também pela abordagem sócio histórica que autoriza. A análise não incide necessariamente sobre a obra em sua totalidade: ela pode se apoiar sobre estratos, pesquisar "séries", compor conjuntos. E a crítica também não se limita ao filme, ela se integra ao mundo que o rodeia e com o qual se comunica, necessariamente. Nessas condições, não seria suficiente empreender análise de filmes, de trechos de filmes, de planos, de temas, levando em conta, segundo a necessidade, o saber e a abordagem das diferentes ciências humanas. É preciso aplicar esses métodos a cada um dos substratos do filme (imagens, imagens sonorizadas, não sonorizadas) as relações entre os componentes desses substratos; analisar no filme tanto a narrativa quanto o cenário, a escritura, as relações do filme com aquilo que não é o filme: o autor, a produção, o público, a crítica, o regime do governo. Só assim se pode chegara compreensão não apenas da obra, mas também da realidade que ela representa. (FERRO, 1992, p.87).
} 
Figure 1: Posters of the films West Side Love, Hair and Saturday Night Fever.

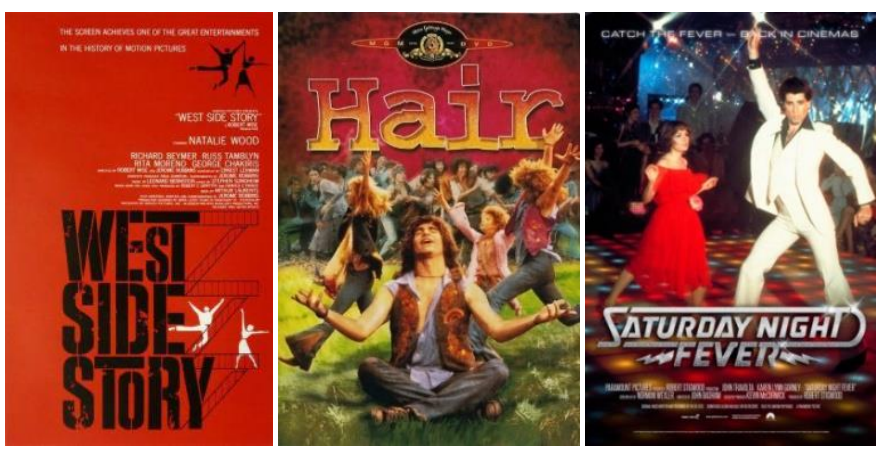

Source: http://www.adorocinema.com/filmes/filme-208/.

\section{THE RESURGENCE OF THE MUSICAL FILM IN THE DECADE OF 1960-1970}

Musical Film is a comprehensive classification for films that have narrative driven by songs. According to Souza; et al. (2011, p. 2), "musical film is a genre of film, in which the narrative relies on a sequence of choreographed songs, using music, songs and choreography as a form of narrative." The musical film can also be a drama, a comedy, a horror story, etc., and despite being labeled as an escapist and alienating genre, its enormous success, since the beginning of sound films, has captured great public and successes in Hollywood's history. According to Souza (2005), the musical style of films had its golden age in the decades between 1930 and 1950, when cinema was the most important form of popular entertainment.

In the 1960 s and 70s, according to Souza (2005, p.5), "as the studio system declined and television grew, musicals went down in the United States,". When the success of musical films was no longer so obvious, new themes were introduced as a way of attracting audiences.

The explosion of the "Baby Boomers"3, teenagers and young consumers demanded a new market of objects,

\footnotetext{
${ }^{3}$ Baby Boomers is the generation born after World War II until the mid-1960s. The expression comes from the term "baby boom," which represents the explosion in the birth rate in the United States in the post-war era and which constituted an important market consumer due to purchasing power and demands of a young market.
} 
clothes, accessories, and mainly entertainment. In order to meet this new pattern of consumption, issues related to youth conflicts and influences of diverse musical types linked to youth provided a new thematic perspective to cinema studios (SOUZA, 2005). Another important theme of the time was those behind the scenes of the musical world, as well as a plurality of approaches and experiments, responsible for successes that resurrected and strengthened the musical style. Famous directors and screenwriters became involved in the productions, as well as choreographers, composers, musicians and bands already consecrated, which gave them many awards.

Some productions of musical films were directed to the young public, approaching a thematic related to the problems and youth conflicts. The soundtracks of the musicals, combined with the choreographies, made some films reference of the young culture of its time. Consequently, the costumes presented showed a significant influence on fashion, when they were admired and imitated by the young crowed. According to Lipovetsky (2015), youth identities are constituted by the appropriation of objects, clothes and models often presented by the favorite movie stars and singers, in this case the design should privilege the tastes and preferences of this youth as a way of approaching this consumer market.

\section{CLASSIFICATION OF CINEMA COSTUMES}

The global reading of the costume is characterized by a series of formal and cultural premises of the cinematographic discourse, giving attention to the gestures of the body and its connection to fashion and its idiosyncrasies, especially those

Source: financial dictionary, available at <https://www.dicionariofinanceiro.com/baby-boomers/> access on 27 jun. 2018. 
that manage to involve the viewer in the narrative due to the fact that they are familiar and live similar situations to those of their daily life and cultural context. The costume, then, often reflects the habits and customs of society to which the film project refers, using as a source for research on the habits and customs of a society identified there, through correct symbolic interpretation and its idiosyncrasies. For the decoding of the film costumes as an element of identification of the socioeconomic role portrayed in the production, it is necessary to establish a classification, to identify their ties with reality and what has to do with the complexity and composition of the character.

Gerard Betton, in his book The Aesthetics of Cinema (1987), makes the following classification of cinema costumes: 1) Realistic costumes, with all the costumes that depict the clothing of the time represented by the film with historical accuracy, 2) para-realists, when the costume designer is inspired by the fashion of the time to carry out his work, but proceeding from stylization, where the preoccupation with style and beauty prevails over pure and simple exactitude and 3) symbolic, when historical accuracy completely loses importance and gives way to the function of symbolically translating characters, soul states, or creating dramatic or psychological effects.

In Betton's (1987) analysis, it is not clear how the costumes of films that portrays another time different from the time of their production are classified. In order to analyze the films in the way they are inserted in a chronological time line, which is very relevant when one has the perspective of a fashion design, this article proposes a new classification of costumes, which are the following: a) Time period reproduction, b) contemporary costumes, and c) free period of time interpretation, and that, in general, film projects can be divided into these three categories. 


\section{A) TIME PERIOD REPRODUCTION}

The time period reproduction has been one of the great sources of publicity of clothing research since the beginning of cinema, for Marc Ferro (1992), "the cinema is a singular testimony of its time, since it is outside the control of any instance of production, mainly the State. Even censorship cannot dominate it". Other historians also debated the subject as german Kracauer (1947) in Kornis (1992, p.241) "considered that the films of fiction immediately reflected the mentality of a nation, establishing a direct relationship between the film and the medium that produces it". In possession of resource facility, throughout its history, the Hollywood film industry has not measured efforts to rebuild other time periods as authentically as possible. In this classification, the likelihood must be the closest to reality, within the possibilities provided by the available materials. The research on all types of material often offers the form of clothing used, as well as other materials used, pattern of colors, etc., producing a rich collection of clothes, accessories, jewelry, hairstyles, makeup and scenography used in the production of the work.

Nevertheless, we cannot forget the temporality of production, which often imposes certain aesthetic aspects related to the time period of the film, regardless the reality to be portrayed. We can often see in the biblical and epic films produced in the 1940s, types of cuts in women's clothing, as well as hairstyles and make-up, which are characteristic of fashion that prevailed during the production of the film. This is the case of the film Samson and Delilah (1949), as shown in figure 2. The dress exhibits the striking characteristics of the fashion of the moment of filming, embroidery and makeup that were not part of the aesthetic universe of the time portrayed in the film.

Figure 2: Scene from the movie "Samson and Delilah" (1949). 


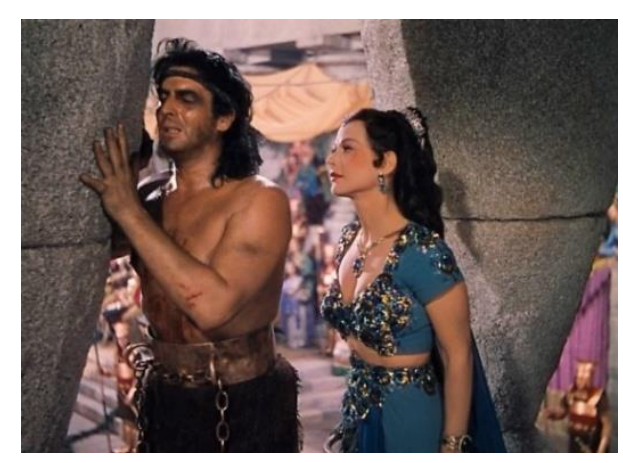

Source: https://3.bp.blogspot.com/-T1Ib_gDbyw/V9nAeaCi3VI/AAAAAAAAUN8/Eoxwp7xsCcUzjN_4foBkfVoEt j140jzqACLcB/s640/samsonanddelilah-bluray-07.jpg.

In Cleopatra (1963), despite the costumes, which according to many film critics were considered "stunning" and a further attraction of the film, the dresses of the actress Elizabeth Taylor, clearly show the influence of fashion from the time of the film's production, in the years 1960, as shown in Figure 3. The green dress worn by the actress could be worn at any time off the canvas. The modeling structure of the brown dress also clearly shows the style of modeling in the 1960s, with well-defined breasts.

Figure 3: Scenes from the movie "Cleopatra" (1963).

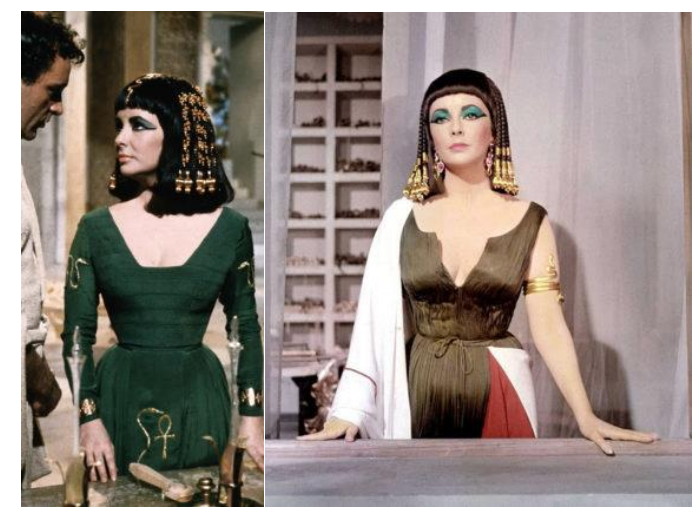

Source: http://cinemaclassico.com/wpcontent/uploads/2017/04/2elizabeth3-206x420.jpg.

In more recent projects the concern with verisimilitude has been growing stronger and the films are true studies in terms of clothing, costumes and scenography. An important 
example is the film "The Passion of the Christ" (2004) with Mel Gibson, which in addition to the concern with the language, spoken in Aramaic, brings impeccable costumes, in the materials used, forms and models, accessories, and other scenographic aspects. Figure 4 shows the texture of the fabric and the detail of the sandal.

Figure 4: Scene from the film "The passion of the Christ" (2004).

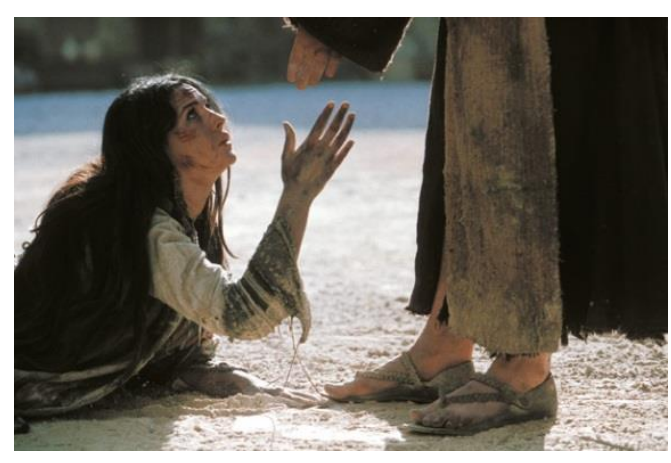

Source:

http://br.web.img3.acsta.net/r_1920_1080/medias/nmedia/ 18/35/22/44/18375164.jpg.

Some series produced for TV, have also shown valuable works in the reproduction of the time period, by the improvement of the costumes and scenography, as in the case of the series "Downton Abbey" (2010), with pieces that show the cut formats of collars, buttons of the coats, houses of handmade buttons and many other details extremely authentic, being able to carry to the screen an atmosphere of times past.

The costume often serves as an element to identify the character and separate it from the persona of the author who interprets it, as well as separating it from other types and characters in the gallery of interpretations of the actor. Famous actors have a constant presence in the media and become familiar to the audience - to make 
them look like people different from those seen in news and social columns, their characters must look different on the movie screen. At this point goes the costume creating elements for each character (COSTA, 2002, p.40) $)^{4}$.

This way, allied to the scenography, the costumes make a bridge with the past, making the experience lived by the viewer quite authentic.

\section{B) CONTEMPORARY COSTUMES}

The characterization task of a character in the production of a film goes beyond the interpretation of the actor, by the elements that make up his image. We can then talk about costume, which includes clothes and accessories, makeup and hair. This universe contributes so that the actor acquires the necessary atmosphere for his interpretation and the costumes assume a character of communication.

In the case of the production of contemporary costumes, in addition to the time of the production of the film, some elements must be taken into account by the costume designer, so that the result reaches the goal within the plot. One should consider the social and economic position of the character, the personality traits and the inner life of the characters who inhabit the fictional world. The clothing has a close connection with the psychological characterization of the characters, their connection and hierarchy in relation to the others, their contextualization in the space of action, in which the scenes unfold defining it. The hierarchical relationships between characters are evident through the use of clothing, by comparing the types of clothing, props, characterization, gestures, attitudes and scenarios, the latter contributing

\footnotetext{
${ }^{4} \mathrm{O}$ figurino muitas vezes, serve como elemento para identificar o personagem e separá-lo da persona do autor que o interpreta, além de separá-lo de outros tipos e personagens da galeria de interpretações do ator. Atores famosos têm presença constante na mídia, e se tornam familiares para a plateia - para fazê-los parecerem pessoas diferentes daquelas vistas em noticiário e colunas sociais, seus personagens devem parecer diferentes na tela de cinema. Neste ponto entra o figurino criando elementos próprios para cada personagem. (COSTA, 2002, p. 40)
} 
greatly in the characterization of the characters, because "they offer or suggest the appropriate background to action "(Carpinteira, 2011).

To create the connection and involvement between spectator and character, pieces of the public's everyday clothing need to be introduced to the costumes and set design, creating links of emotion with the character and involvement in the plot. At the moment, we can make the connection between cinema and fashion, as the costume designer takes on the responsibility of introducing certain items of clothing that will influence the daily lives of people.

We start now analyzing the relationship between fashion and cinema, both sellers of representations, dreams and fantasies. Thus, cinema is no longer just a reference of fashion and behavior and is now also a fashion industry.

This fashion / cinema relationship is not current, it comes especially from the $30 \mathrm{~s}, 40 \mathrm{~s}$ and $50 \mathrm{~s}$ when there was no television and it reigned absolute. Not only the costumes were copied, but also the attitude of the actors, the way of smoking, sitting and walking was imitated. Direct from the "telonas", the scenes were released through the press, by magazines for the public that paid to know how their favorite artists lived (BATTISTI, 2009, p.2) ${ }^{5}$.

The interconnection of the fashion system and the cinema has become present since the first decades of Hollywood cinema. Some renowned costume makers have partnered with big names in haute couture to build their

\footnotetext{
${ }^{5}$ Essa relação moda/cinema não é atual, vem, especialmente, das décadas de 30, 40 e 50 quando não havia a televisão e ele reinava absoluto. Não somente os figurinos eram copiados, mas também a atitude dos atores, o modo de fumar, sentar e andar era imitada. Direto das "telonas", as cenas eram divulgadas via imprensa, por revistas para o público que pagava para saber como viviam seus artistas prediletos (BATTISTI, 2009, p. 2).
} 
characters' costumes. As was the case with Alfred Hitchcock's costume for "Vertigo" (1958). The protagonist, played by the actress Kim Novack (1933-), lived two characters within the plot, so, for the viewer to distinguish them, the costumes became a fundamental part of the plot. One of the characters is a girl of simple and vulgar origin, and the other, a rich girl of society, who to excel in one of the main moments of the film wears a costume by the fashion designer Hubert de Givenchy (1927-2018), great French stylist who dressed many actresses in Hollywood, differentiating the character with class and elegance. (Figure 5)

Figure 5: The actress Kim Novack and her two characters in the film Vertigo(1958).

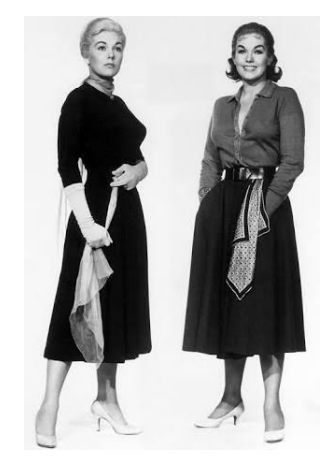

Source:

http://68.media.tumblr.com/e2b238f1f2a9bcb7eab05c7a61ed6901 /tumblr_n6c79jw6i01sw9yuuo1_500.png.

Other contemporary films that stand out in the interplay of costumes / fashion are "The Devil Wears Prada" (2007) and the two films in the series "Sex in The City" (2008 to 2010). It is important to note that in these three films the costume is part of the storyline, almost as if it were an extra character that stands out and is present throughout the film. In this work the costumes were carefully constructed for each character, in addition to showing true collections of international haute couture, influencing the fashion scene of the time. 
C) FREE PERIOD OF TIME INTERPRETATION

Many films, while depicting a specific historical period of time, often prioritize dramatic and psychological aspects to the detriment of aspects of temporal fidelity. They are films that, although the costumes and scenography insert the spectator in a specific time and space, a historical context, provides a less real, more manipulative and timeless atmosphere. They choose the styling that prevails over precision. We can exemplify with the film "Marie Antoinette" (2007), where although there is precision in relation to the historical moment of the film, there was an intentionally fanciful atmosphere, often provided by an exaggeration in the composition of the costumes.

Movies in which the subject matter is the future will always be included in this classification. However, they are often referred to or inspired by the past. As it is the case with Blade Runner (1982), where the costume of the main character, the detective lived by the actor Harrison Ford in the city of Los Angeles of 2023, was inspired by the costume of another detective, but of the 1940s, lived by the actor Humphrey Bogart. Another example of a futuristic film, which uses free-time interpretation, is the movie "Barbarella" (1968), in which the story happened in the 31st century and was launched at the height of the "space age", a year before the man stepped on the moon. The costumes tried to portray the future, but it was produced by a renowned designer of the time, Paco Rabane, figure 6. We cannot know for sure if the film, with its box office success, influenced the fashion of the time, or if the fashion of the time found space within the movie.

Figure 6: Costume of the film "Barbarella" (1968). 


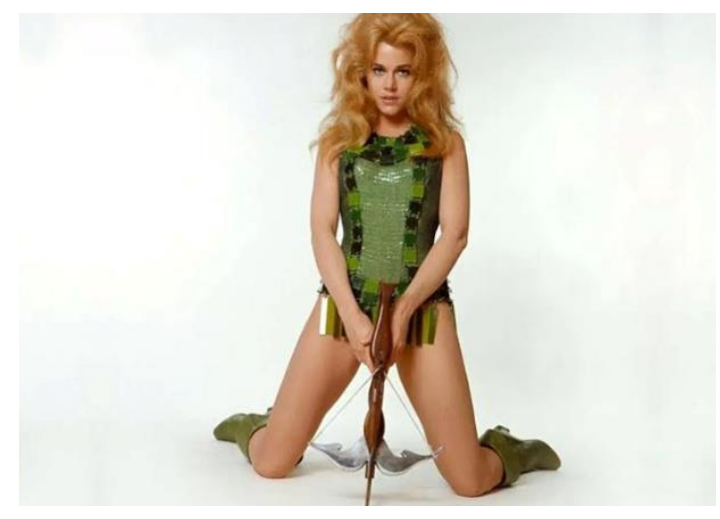

Source: http://universoretro.com.br/wpcontent/uploads/2016/03/barbarella-figurino.jpg.

We can understand that there is no rigid and exclusive classification in relation to cinema costumes. We only use certain parameters as a research methodology.

\section{ANALYSIS OF THE WORKS}

The analysis of these works aims to exemplify the proposed classification and contextualize in the films, the relationship fashion / cinema and society of each period.

In West Side Story, directed by Robert Wise (1961), inspired by a musical homonym of Broadway, the theme of the Puerto Rican immigrants in New York and the rivalry of gangs formed by groups of New Yorkers, the "Jets" and the group of Puerto Ricans, the Sharks. The whole plot revolves around the forbidden romance of the girl Puerto Rican Mary and the American Tony. The plot is clearly an allusion to the Shakespearean novel "Romeo and Juliet" (love forbidden by rivalry between two groups), tragically ending with the separation of the couple by the death of Tony. "Choreography integrates the songs into the movie's plot and there are no separations between dramatic action and musical sequences, which was innovative for the time" (SOUZA, 2005).

The costumes of the film, produced at a contemporary moment by the costume designer Irene Sharaff (1910-1983), 
are concerned to provide identity to the two rival gangs. This way, the costumes, which needed to adapt to the dance numbers were composed of clothes of the fashion of the time, being the identity conferred through the use of colors. For Puerto Ricans the colors used for the clothes were generally red, black, brown and earthy tones as shown in figure 7. Already in the costumes of the Americans were used lighter colors and pastels such as green, blue and yellow, figure 8 . The costumes have a character of differentiation within the context of the film.

Figure 7: The earthy tones and lighting reinforce the Puerto Rican costumes in choreography.

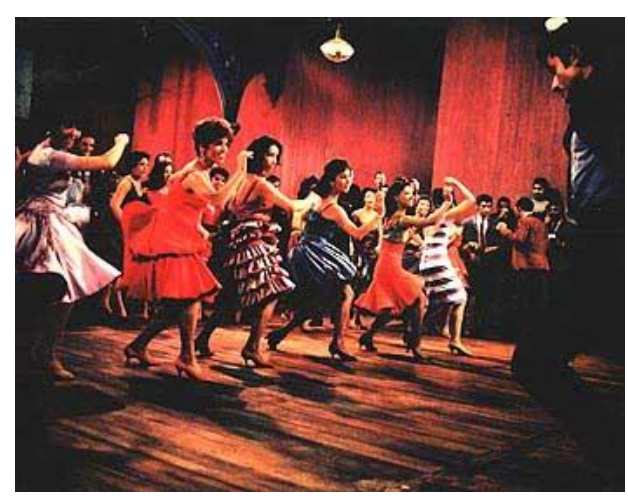

Source:

http://br.web.img3.acsta.net/r_1920_1080/medias/nmedia/18/36 /35/66/18629180.jpg.

Figure 8: Colors as an element of differentiation between gangs in the movie West Side Story. 


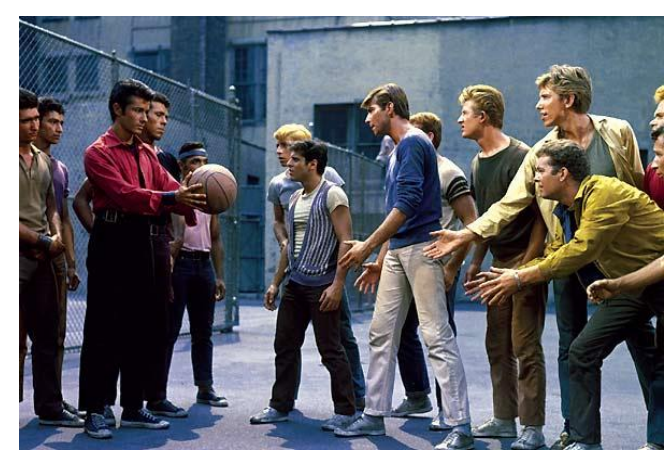

Source:

http://br.web.img3.acsta.net/r_1920_1080/pictures/17/03/23/10/

26/179759.jpg.

In "Hair," directed by Milos Forman (1978), other issues concerning youth were covered: the Hippie movement, drugs and the Vietnam War. In this production, inspired by the musical homonym of Broadway, music and choreography also merge with the plot of the film in an extremely successful way, involving the audience.

Joining the hippie movement to music was an obvious solution, but it guaranteed the film to perform its musical sequences without escaping reality. The madness and freedom of expression, usually associated with the hippies, allowed the characters to go out singing and dancing in the streets without this being considered unreal. The fantasies and hallucinations were justified by the use of drugs (SOUZA, 2005, p.112).

The costume, produced by the costume designer Ann Roth (1931-), was a reproduction of period, despite the chronological distance. The hippie ideology was transposed into the film through the composition of the hippie characters' core costumes, through ornamented and colorful dresses with bell-bottoms, floral blouses, smocks, floral and ethnic prints,

\footnotetext{
${ }^{6}$ Associar o movimento hippie à música era uma solução óbvia, mas que garantiu ao filme realizar suas sequências musicais sem fugir da realidade. A loucura e a liberdade de expressão, normalmente associadas aos hippies, permitiam que os personagens saíssem cantando e dançando pelas ruas sem que isso fosse considerado irreal. As fantasias e alucinações eram justificadas pelo uso de drogas (...) (SOUZA, 2005, p.112).
} 
fringes, leather goods, flowers in the hair, stamped shawls, long and misaligned blackpower hair, everything in a light atmosphere, very tipical of this culture. The protagonist, who did not belong to the group, dressed in a classic way, with elegant accessories, even being young, demonstrating clearly the social class to which it belonged. Two moments stand out in relation to the costumes, the one of a party in the house of the protagonist, figure 9 , in which she and her friends received the guests in elegant clothes and very young in light shades, showing the position of young debutantes.

Figure 9: Scene of a party that shows the formality and youthful form of the main actress and her friends.

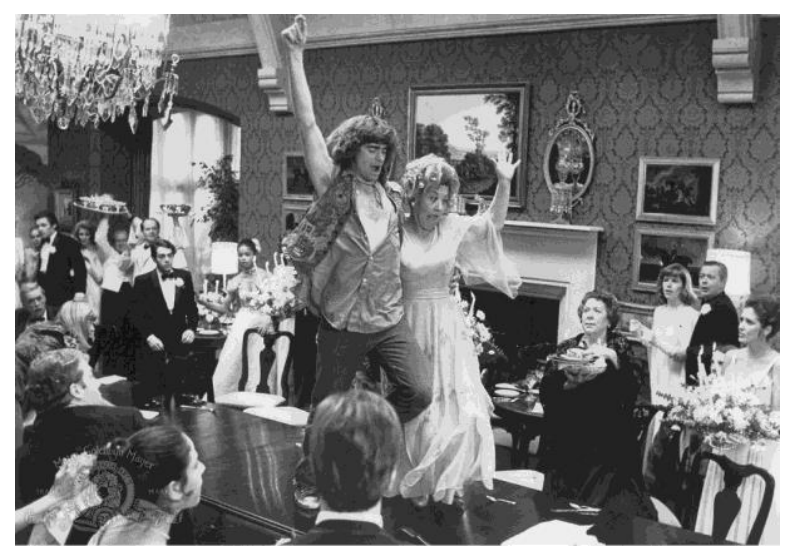

Source: https://ia.mediaimdb.com/images/M/MV5BMTg00TY3ODc5OF5BMI5BanBnXkFtZTc wMTc4MjkzNA@@._V1_.jpg.

Another moment stands out in a scene of hallucination or dream, with fanciful and diaphanous costumes, well suited to the dreams and hallucinations produced by the use of drugs, characteristics of the time. (Figure 10)

Figure 10: Costume of the hallucination / dream scene. 


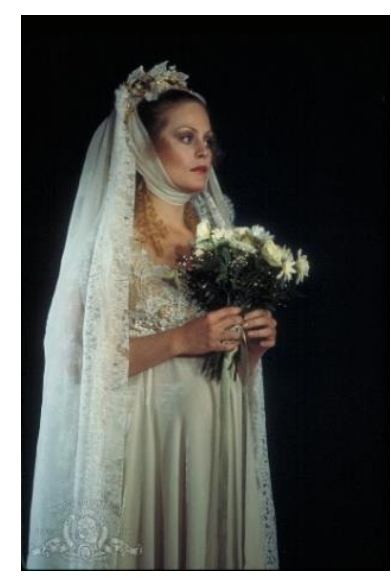

Source: https://images-na.ssl-imagesamazon.com/images/M/MV5BMjI2NjYzMzYzOF5BMI5BanBnXkFtZTc wNTc4MjkzNA@@._V1_SY1000_CR0,0,666,1000_AL_.jpg.

Although the film Hair has not been as successful as the musical in terms of public and criticism, its influence in the fashion was quite considerable, because it was responsible for a redemption within the fashion of a so outdated culture, the hippie culture, that today is part of the collective memory of the aesthetics of the 1970s.

The film "Saturday Night Fever", directed by John Badham (1977), tells the story of a young descendant of Italian immigrants, living in the suburbs of New York, who finds joy in the dance of the nightclubs, becoming the "king of discotheques ". Taking advantage of the fever of the clubs and an unprecedented soundtrack of the group already known, Bee Gees, the film was one of the greatest successes of the genre in all the times.

The music and dance scenes are part of the storyline, built around a dance and romance contest between partners. The film also tackles themes inherent to the youth of the time as sexual freedom, drugs and dance, and to this theme one must credit its success.

The contemporary costumes, signed by Patrizia von Brandenstein (1943-), followed the dress patterns of the youngsters of the lower middle class of the United States at 
the time and served to spread around the world the "disco" style, consisting of a novelty that the male costumes was more successful than the female. In this case, the light suit worn with dark shirt and boots by John Travolta's character Tony Maneiro, was copied extensively on the dance floor for many years to come, and in addition, the film showed an extremely vain man without questioning his manhood. The legendary opening scene of the film shows the character walking on a rhythmic pace through the streets of New York wearing jeans, a red shirt, a leather jacket and boots, also a fashion icon from the 1970s. (Figures 11 and 12)

Figure 11: Early scene of the movie "Saturday Night Fever".

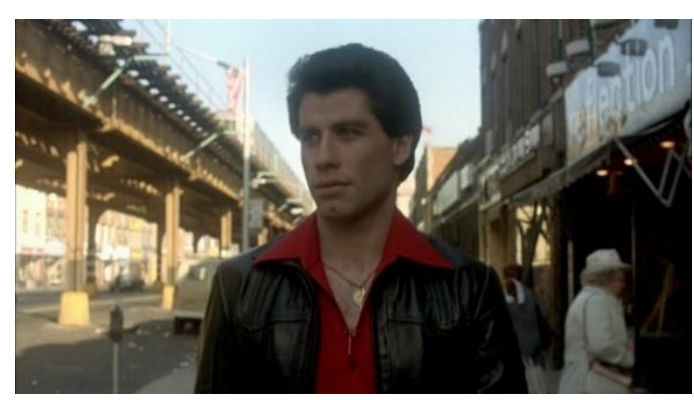

Source:

http://br.web.img3.acsta.net/r_1920_1080/pictures/210/417/210 41777_2013091916041069.jpg

Figure 12: The classic costume of the dance floors of the 1970.

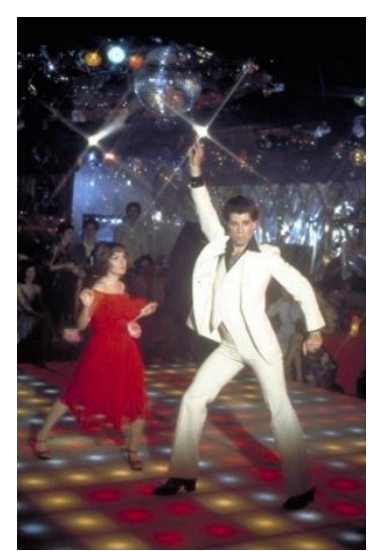


http://br.web.img3.acsta.net/r_1920_1080/pictures/17/05/17/15/

28/142087.jpg.

The analysis of the chosen films shows, in an exemplified way, how cinema can be part of the historical research of the costumes as well as of other aspects characteristic of a time period, such as scenography, habits and customs of a social group, even though the point of view of the creators of the film project. The historical context is impregnated in the images and as Marc Ferro (1987) said, "fourteen minutes of a film speaks more than two hours of lectures"7, about a documentary film covering racism in the United States.

\section{CONCLUSIONS}

In its more than one hundred years of existence, the "Seventh Art" as the cinema is considered, can provide endless interpretations. Several aspects can be evaluated and analyzed independently or together, scenography, language, photography, etc. Analyzing the costumes of musical films in order to search for historical sources of research and their relationship with fashion is one of the many possibilities that the design provides within the filmic universe.

Films like West Side Love, Hair and Saturday Night Fever are examples of musical cinematographic productions, which marked a time by approaching the theme of youth conflicts, together with unforgettable soundtracks. These films have become classics of cinematography and are true documents of their time. The analysis of their costumes through design and the influence exerted by them in fashion, provides a knowledge of the societies that each film represents. The city

\footnotetext{
${ }^{7}$ Conference held at the Faculty of Sciences and Letters of Assis, UNESP, on August 27, 1987. Youtube, access on June 02. 2018.
} 
of New York was the main scene where the plots of the three films chosen to happen. In West Side Love, the contemporary costumes characterize the differences between the two societies portrayed. The conflicting interests among young Americans and the new generation of Puerto Rican immigrants were shown by choosing the color palette of each group's clothing. In Hair, the reconstitution of the "hippie" costume, influenced the fashion of the time and the differences of costumes made clear, within the story of the plot, the evident distancing between the characters belonging to different social classes. And in "The Saturday Night Fever," contemporary costumes marked their era as fashion icons of the late 1970 s along with a soundtrack enshrined in the hit charts of the time.

Through providing a way to classify the costumes of the films, this text intends to serve as a catalyst for future explorations within the theme of the interaction of cinema and fashion and that through the interpretation of elements of the costumes the cinema can also serve as an important source of historical research in the field of fashion.

\section{REFERENCES}

BATTISTI, Francisleth Pereira. Moda e figurino: unilateralidade. Publicação $1^{\circ}$ Encontro Paranaense de Moda, Design e Negócios. Maringá, 2009.

BETTON, Gerard. A Estética do Cinema. São Paulo: Martins Fontes, 1987.

DE LA HAYE, Amy. Fashion Sourcebook: A Visual Reference to Twentieth Century Fashion. London: Macdonald \& Co Ltda, 1988.

CABRAL, Alexandra; FIGUEIREDO, Carlos Manuel. O Figurino na Construção das Personagens e do Drama da Ficção Cinematográfica. CIAUD - Centro de Investigação em Arquitectura, Urbanismo e Design - Faculdade de Arquitectura da Universidade Técnica de Lisboa, $8^{\circ}$ SOPCOM Comunicação Global, Cultura e Tecnologia, 2016. 
CARPINTEIRA, Yolanda Maria Garcia. A Intervenção do Designer de Produção na Peça Cinematográfica. Dissertação para obtenção do grau de mestre em design de comunicação. Faculdade de Arquitetura, Universidade Técnica de Lisboa, 2011.

COSTA, Francisco Araújo da. O figurino como elemento essencial da narrativa. Sessões do Imaginário. Porto Alegre, no 8, ago, FAMECOS/PUCRS, 2002.

FERRO, Marc. Cinema e História. Rio de Janeiro: Paz e Terra, 1992

KORNIS, Mônica Almeida. História e Cinema: um debate metodológico. Estudos Históricos, Rio de Janeiro, vol. 5, n. 10, 1992

LIPOVETSKY, Gilles; SERROY, Jean. A Estetização do Mundo, Viver na Era do Capitalismo Artista. São Paulo: Companhia das Letras, 2015.

SOUZA, Christine Veras. O Show Deve Continuar: O gênero musical no cinema. Dissertação de mestrado, Escola de Belas Artes, UFMG, BH, 2005.

SOUZA, Amanda; et al. A Retomada do Gênero Musical. São Carlos, SP, 2011.

Sites:

Adoro Cinema <http://www.adorocinema.com/filmes/filme$980 /$ fotos/detalhe/?cmediafile $=18886613>$. Acessado em 20/06/2017

IMDB

Shttp://www.imdb.com/title/tt0079261/mediaviewer/rm372 8246016 $\geq$. Acessado em 20/06/2017

Filmes:

AMOR SUBLIME AMOR (West Side Story - EUA-1961). Direção: Robert Wise e Jerome Robbins.

EMBALOS DE SÁBADO À NOITE, OS (Saturday Night Fever EUA - 1977). Direção: John Badham.

HAIR (EUA - 1979). Direção: Milos Forman. 